\title{
Parasitism by Campoletis flavicincta on Spodoptera frugiperda in corn
}

\author{
Fausto da Costa Matos Neto(1), Ivan Cruz $^{(2)}$, José Cola Zanuncio(3), Carlos Henrique Osório Silva(4) \\ e Marcelo Coutinho Picanço(3)
}

\begin{abstract}
(1)Universidade Federal de Viçosa (UFV), Dep. de Fitotecnia, CEP 36571-000 Viçosa, MG. E-mail: fmatos@cnpq.br (2)Embrapa Milho e Sorgo, CEP 35701-970 Sete Lagoas, MG. E-mail: ivancruz@cnpms.embrapa.br(3)UFV, Dep. de Biologia Animal. E-mail: zanuncio@ufv.br, picanço@ufv.br (4)UFV, Dep. de Informática. E-mail: chos@dpi.ufv.br
\end{abstract}

\begin{abstract}
Parasitism by Campoletis flavicincta (Ashmead) (Hymenoptera: Ichneumonidae) on Spodoptera frugiperda (Smith) (Lepidoptera: Noctuidae) and consequent reduction of production losses were evaluated on caged corn plants in the field. Treatments consisted of plots infested with 0 (control), 15 and 30 pairs of C. flavicincta with egg masses per cage and plot infested without cage and liberation of the parasitoid. Parasitoid release was done when S. frugiperda larvae were three-day-old. Fifty corn plants (40\%) per plot were collected seven days after infestation and $S$. frugiperda larvae present were reared in glass cups on an artificial diet. Number of S. frugiperda larvae was reduced by C. flavicincta but mortality of the pest and parasitoid sex ratio in laboratory were similar among treatments. Total progeny and female production from collected larvae were similar among densities of released parasitoid. Parasitism rate was higher on 30 than on 15 pairs of $C$. flavicincta. Damage on corn plants at seven and 14 days after $S$. frugiperda infestation had similar grades at 0,15 or 30 C. flavicincta pairs and higher values than the plots without cage. Damage by S. frugiperda was lower at 30 C. flavicincta pairs after 21 days of infestation. Final stand, stand reduction by plant death and corn productivity were similar among treatments.
\end{abstract}

Index terms: field cage evaluation, corn pests, biological control, parasitoid density, Ichneumonidae.

\section{Parasitismo de Campoletis flavicincta sobre Spodoptera frugiperda em plantas de milho}

\begin{abstract}
Resumo - O objetivo deste trabalho foi avaliar o potencial do parasitóide Campoletis flavicincta (Ashmead) (Hymenoptera: Ichneumonidae) no controle de Spodoptera frugiperda (Smith) (Lepidoptera: Noctuidae) em plantas de milho protegidas por gaiolas no campo. Os tratamentos consistiram de parcelas infectadas com 0 (controle), 15 e 30 casais de $C$. flavicincta liberados por gaiola e parcela infestada, além de parcelas sem gaiola e sem liberação do parasitóide. C. flavicincta foi liberado quando as larvas de S. frugiperda estavam com três dias de idade. Em cada parcela, $40 \%$ das plantas foram colhidas sete dias após a infestação, e as larvas de S. frugiperda presentes foram transferidas para copos com dieta artificial. C. flavicincta reduziu o número de larvas, mas a mortalidade natural das larvas e a razão sexual do parasitóide emergido em laboratório foram semelhantes entre tratamentos. A produção de progênie e de progênie fêmea por $C$. flavicincta foi semelhante nas amostras de 15 e 30 casais, mas a taxa de parasitismo foi maior nas amostras de 30 casais do que nas de 15 . Os danos às plantas por larvas de $S$. frugiperda, aos sete e 14 dias após a infestação, foram semelhantes entre as parcelas com 0,15 ou 30 casais de C. flavicincta, maiores do que nas parcelas sem gaiola. Esses danos foram menores nas parcelas de 30 casais do parasitóide, após 21 dias da infestação. O estande final, redução no estande pela morte das plantas e a produtividade do milho foram semelhantes entre tratamentos.
\end{abstract}

Termos para indexação: avaliação em gaiola de campo, pragas do milho, controle biológico, densidade do parasitóide, Ichneumonidae.

\section{Introduction}

Parasitoids are commonly used in biological control programs in the world. Evaluations made from field collections showed the presence of the solitary larval endoparasitoid Campoletis flavicincta (Ashmead) (Hymenoptera: Ichneumonidae) parasitizing initial instars larvae of the fall armyworm Spodoptera frugiperda (Smith) (Lepidoptera: Noctuidae), which is considered the main corn pest in Brazil. Moreover, laboratory data 
on the biology of this parasitoid (Cruz et al., 1995, 1997) support field studies.

Natural enemies can be evaluated in the field using cages (Van Driesche \& Bellows, 1996), which is a practical method to perform initial studies on efficiency of these biological control agents because it is an intermediate stage between laboratory and field conditions. Due to limitations of this method, results should be analyzed carefully, although this technique has been used by many researchers to evaluate potential of parasitoids and their impact on non-target organisms (Luck et al., 1999).

The objective of this work was to evaluate the potential of Campoletis flavicincta against Spodoptera frugiperda in caged corn plants in the field.

\section{Material and Methods}

The experiment was conducted in plots of corn cultivated with the HT 7105-3 hybrid at Embrapa Milho e Sorgo, from September to February 2001.

Each experimental plot was composed of 125 plants distributed in five meter-long rows of corn, spaced by $0.9 \mathrm{~m}$ between rows and $0.2 \mathrm{~m}$ within rows. These plants were cultivated according to technical recommendations of Embrapa Milho e Sorgo, without pesticides. Corn plants about 21 days old (5-6 leaves) were enclosed by organza cage $(5 \times 4 \times 2 \mathrm{~m})$. Any pest present in these plants were manually removed before caging. Twenty five plants per cage (20\%), which corresponds to the economic threshold for this pest (Carvalho, 1978; Cruz, 1995), were infested with one egg mass (three-day-old) of S. frugiperda using about 100 eggs (average number of eggs/egg mass of this pest in the field) per plant (Cruz, 1995).

The parasitoid $C$. flavicincta was released when $S$. frugiperda larvae were three-day-old and treatments were represented by densities of 0 (control), 15 and 30 pairs of the parasitoid (c.a. three to six-day-old) per cage. These parasitoids were obtained from laboratory facilities of Embrapa Milho e Sorgo where they were maintained after emergence in glass rearing cages receiving a solution of sugar (5\%) and ascorbic acid $(0.05 \%)$. Evaluation on natural biological control of the fall armyworm by $C$. flavicincta was made in plots infested with egg masses of $S$. frugiperda, using the same infestation technique, but without cage or release of this parasitoid.

Pesq. agropec. bras., Brasília, v.39, n.11, p.1077-1081, nov. 2004
Five replications were used in a completely randomized block design. Cages were removed after seven days and damage was visually evaluated after seven, 14 and 21 days of pest infestation by a scale (Cruz \& Turpin, 1982) from 1 to 6 , in which 1: no damage; 2: scraped leaves plants; 3 : holed leaves plants; 4: torn leaf plants; 5: damage in the whorl (holed or torn); 6 : whorl destroyed plants. Plants of the two external rows of each plot were taken to the laboratory at the end of the first evaluation to collect $S$. frugiperda larvae. These larvae were individualized in $50 \mathrm{~mL}$ glass cups, on an artificial diet (Cruz, 2000) until pupation of the larvae or emergence of parasitoid, to determine parasitism rate, sex ratio and mortality of $S$. frugiperda. Grain yield $\left(\mathrm{kg} \mathrm{ha}^{-1}\right)$ of corn plants was evaluated in the three remaining rows.

Variance and regression analysis were performed and mean number of larvae collected, percentage of host mortality, total progeny, female progeny, sex ratio, parasitism, final stand, stand reduction (\% of dead plants) and grain yield were compared through Tukey's test PROC GLM (SAS Institute, 1989). The mixed linear model $Y_{i j k}=\mu+\tau_{i}+\beta_{j}+\gamma_{k}+(\tau \gamma)_{k i}+\varepsilon_{i j k}$, in which $\tau_{\mathrm{i}}$ is the fixed effect of the $\mathrm{i}$-th treatment; $\beta_{\mathrm{j}}$ is the random effect of the j-th block; $\gamma_{k}$ is the fixed effect of the k-th time; $(\tau \gamma)_{\mathrm{ki}}$ is the random effect of the interaction treatment vs. time; and $\varepsilon_{\mathrm{ijk}}$ is the random error, considering the usual presuppositions (Littel et al., 1996) were adopted for the variable damage grade. The theory of mixed models PROC MIXED (SAS Institute, 1989) was used to calculate adjusted means (least-square means) and the respective standard error. Adjusted means based on estimates of least square of the parameters were used due to unbalance of data of damage grade, that is, unequal number of replications per treatment, LSMEANS - PROC MIXED (SAS Institute, 1989).

\section{Results and Discussion}

Number of S. frugiperda larvae was lower in plots without cage $(\mathrm{P}<0.05)$ than in plots with 0 or 15 C. flavicincta pairs, but it was similar to the treatment that used 30 pairs of this parasitoid (Table 1). Number of larvae was also lower $(\mathrm{P}<0.05)$ in plots of 15 or 30 pairs than in cages without parasitoid (Table 1), a decrease of $42.25 \%$ and $48.25 \%$ on larvae populations of this pest, respectively. An intense cannibalism in cages with parasitoids may account for reductions on number 
of larvae because those parasitized larvae have lower food consumption (Cruz et al., 1997) and, hence, delaying in development is observed. Therefore they may be less active and present lower capacity of defense against attack by non-parasitized larvae. Death of larvae due to oviposition attempts by $C$. flavicincta females or parasitized larvae dropping from leaves could also have reduced their population. This last possibility may not be important because no larvae were observed on the ground.

Mortality of S. frugiperda larvae collected from field cages and reared in the laboratory was similar among all densities of $C$. flavicincta and plots without cages (Table 1). Overall fate of $S$. frugiperda larvae was assessed because Matos Neto (2003) has characterized larval mortality caused by other events from parasitism than only successful parasitoid development and emergence with density increase of C. flavicincta. Therefore, increase densities from 0 to 30 pairs of C. flavicincta could have contributed to reduce population of $S$. frugiperda, although they were not enough to be detected. Indirect mortality of hosts without parasitoid emergence can be enhanced by several factors under multiple parasitism due to increasing parasitoid aggregation per patch, such as larval parasitoid competition inside host, host immunity defense, and stings to marking host or to oviposit.

Progeny (males and females) and female progeny of C. flavicincta were similar $(\mathrm{P}>0.05)$ for both parasitoid densities (15 and 30 pairs). Each female produced an average of 10.93 descendants with 1.57 females (15 pairs) and 9.08 descendants with 1.05 females (30 pairs). These values were calculated considering $40 \%$ of larvae collected per cage - two out of five corn rows. These values are lower than laboratory results for this parasitoid (Matos Neto, 2003). High temperatures - average maximum was $34.6^{\circ} \mathrm{C}$ - and food shortage for C. flavicincta females inside cages may have contributed for these results. This might have reduced longevity, few of them were alive three days after release, and reproductive potential of this natural enemy. Food source may be important for $C$. flavicincta because longevity of Campoletis sonorensis (Cameron) (Hymenoptera: Ichneumonidae) (Lingren \& Lukefahr, 1977) and parasitism rate of Copidosoma koehleri Blanchard (Hymenoptera: Encyrtidae) (Baggen \& Gurr, 1998) on eggs of Phthorimaea operculella (Zeller) (Lepidoptera: Gelechidae) were higher with food.

Sex ratio of $C$. flavicincta progeny was similar among treatments (Table 1). Sex ratio of this parasitoid is around 0.5 in natural conditions, which is higher than that found in laboratory (Cruz et al., 1995), representing a problem at this parasitoid mass rearing. The cause of low sex ratio in C. flavicincta is unknown, but this event was also reported for other Hymenoptera parasitoids reared in the laboratory (Fuester et al., 1987; Zaki et al., 1994). Sex ratio of $C$. flavicincta may have been affected while its adults were in the laboratory, because parasitism occurred in an environment close to natural conditions - interior of field cage - where the sex ratio of C. flavicincta was very low (Table 1 ).

Parasitism rate was higher at 30 than at 15 pairs of C. flavicincta and both treatments showed higher parasitism rate than without cage (Table 1). The increase of parasitism rate with the number of parasitoids released is similar to the results found for Campoletis perdistinctus (Vierick) (Campoletis sonorensis (Cameron)) (Hymenoptera: Ichneumonidae) (Noble \& Graham, 1966). Parasitism rates of $C$. flavicincta could be higher using food inside cages and they may have been underestimated because parasitized larvae are more susceptible to cannibalism in a similar manner as observed in laboratory.

Table 1. Number collected and death of host larvae (DHL) in laboratory of Spodoptera frugiperda (Lepidoptera: Noctuidae) larvae and total progeny, female progeny, sex ratio and parasitism rate (means \pm SE) of Campoletis flavicincta (Hymenoptera: Ichneumonidae) parasitizing S. frugiperda in field cages, with release of 0,15 or 30 pairs of this parasitoid and in plots without cage and whith no release of parasitoids ${ }^{(1)}$.

\begin{tabular}{|c|c|c|c|c|c|c|}
\hline \multirow[t]{2}{*}{ Treatment } & \multicolumn{2}{|c|}{ Fall armyworm } & \multicolumn{4}{|c|}{ Parasitoid } \\
\hline & $\begin{array}{l}\text { Larvae } \\
\text { collected }\end{array}$ & $\begin{array}{c}\text { DHL } \\
(\%)\end{array}$ & $\begin{array}{c}\text { Total } \\
\text { progeny }\end{array}$ & $\begin{array}{l}\text { Female } \\
\text { progeny }\end{array}$ & $\begin{array}{c}\text { Sex } \\
\text { ratio }\end{array}$ & $\begin{array}{l}\text { Parasitism } \\
\text { rate }(\%)\end{array}$ \\
\hline 0 & $509.8 \pm 56.08 \mathrm{a}$ & $11.5 \pm 3.45 \mathrm{a}$ & $-^{(2)}$ & - & - & - \\
\hline 15 & $294.4 \pm 61.99 b$ & $16.7 \pm 6.76 \mathrm{a}$ & $65.6 \pm 15.24 a$ & $9.4 \pm 3.19 \mathrm{ab}$ & $0.15 \pm 0.05 \mathrm{a}$ & $28.64 \pm 3.82 b$ \\
\hline 30 & $263.8 \pm 45.05 b c$ & $16.9 \pm 3.65 \mathrm{a}$ & $109.0 \pm 26.53 \mathrm{a}$ & $12.6 \pm 3.30 \mathrm{a}$ & $0.10 \pm 0.02 \mathrm{a}$ & $46.96 \pm 5.75 a$ \\
\hline Without cage & $96.0 \pm 48.67 \mathrm{c}$ & $21.5 \pm 14.74 a$ & $7.8 \pm 4.61 b$ & $1.8 \pm 1.80 \mathrm{~b}$ & $0.20 \pm 0.20 \mathrm{a}$ & $4.45 \pm 1.93 \mathrm{c}$ \\
\hline
\end{tabular}

(1) Means followed by the same letter, in the column, do not differ significantly by the Tukey's test at 5\% level of probability. (2)Data were not presented because no parasitoid was released in this treatment. 
Damage by $S$. frugiperda on corn plants was lower after seven days of infestation in plots without cage than in the other treatments (Table 2). Damage was similar at 0,15 or 30 pairs of $C$. flavicincta after 14 days of infestation, but plots without cage showed lower damage than the control. Damage on corn plants under releasing of 30 pairs of $C$. flavicincta was lower than in the control after twenty-one days of infestation but damage in plots with 0 or 15 pairs of $C$. flavicincta was higher than in plots without cage. Lower damage at 30 pairs than in the control after 21 days can be due to a reduction on number of $S$. frugiperda larvae (Table 1). Damage by $S$. frugiperda tended to be lower concerning time due to development of new leaves and a consequent recovery of corn plants (Table 2). However no regression model could be adjusted for damage grade considering time (seven, 14 and 21 days after infestation with S. frugiperda).

Final stand, stand reduction (\%) and grain yield $\left(\mathrm{kg} \mathrm{ha}^{-1}\right)$ of corn plants were similar among treatments, although stand reduction was only $4.63 \%$ and $2.79 \%$ in field cages with release of 15 and 30 pairs of C. flavicincta, compared to $8.37 \%$ in the control (no parasitoid released), and grain yield was about $1,000 \mathrm{~kg} \mathrm{ha}^{-1}$ higher with liberation of this parasitoid (Table 3).

Natural biological control in this area was efficient because the number of $S$. frugiperda larvae collected (Table 1) and damage to corn plants (Table 2) were lower in plots without cage than in the control, with similar reduction on stand in plots without cage and in those with release of $C$. flavicincta (Table 3). This natural biological control may be explained by surrounding plant diversity and continuous corn planting, which allows a

Table 2. Damage grade (adjusted means \pm SE) of corn plants after seven, 14 and 21 days of infestation with eggs of Spodoptera frugiperda (Lepidoptera: Noctuidae) in field cages with 0, 15 or 30 pairs of Campoletis flavicincta (Hymenoptera: Ichneumonidae) or in plots without cage and release of this parasitoid $^{(1)}$.

\begin{tabular}{lccc}
\hline Treatment & \multicolumn{3}{c}{ Days after infestation } \\
\cline { 2 - 4 } & 7 & \multicolumn{3}{c}{14} & 21 \\
\hline 0 & $4.17 \pm 0.5010 \mathrm{a}$ & $3.91 \pm 0.5133 \mathrm{a}$ & $3.81 \pm 0.5133 \mathrm{a}$ \\
15 & $4.05 \pm 0.5010 \mathrm{a}$ & $3.77 \pm 0.5133 \mathrm{ab}$ & $3.37 \pm 0.5133 \mathrm{ab}$ \\
30 & $3.85 \pm 0.5010 \mathrm{a}$ & $3.64 \pm 0.5133 \mathrm{ab}$ & $3.11 \pm 0.5133 \mathrm{bc}$ \\
Without cage & $3.26 \pm 0.5010 \mathrm{~b}$ & $3.18 \pm 0.5133 \mathrm{~b}$ & $2.50 \pm 0.5133 \mathrm{c}$ \\
\hline \multicolumn{2}{l}{ (1) Means followed by the same letter, in the column, do not differ } \\
significantly by the t test at $5 \%$ of probability.
\end{tabular}

Pesq. agropec. bras., Brasília, v.39, n.11, p.1077-1081, nov. 2004
Table 3. Final stand, reduction on initial stand (\%) and grain yield $\left(\mathrm{kg} \mathrm{ha}^{-1}\right)$ (means $\left.\pm \mathrm{SE}\right)$ of corn plants infested with egg masses of Spodoptera frugiperda (Lepidoptera: Noctuidae) in field cages with release of 0, 15 or 30 pairs of Campoletis flavicincta (Hymenoptera: Ichneumonidae) or in plots without cage and release of this parasitoid ${ }^{(1)}$.

\begin{tabular}{lccc}
\hline Treatment & $\begin{array}{c}\text { Final } \\
\text { stand }\end{array}$ & $\begin{array}{c}\text { Stand } \\
\text { reduction }(\%)\end{array}$ & $\begin{array}{c}\text { Grain yield } \\
\left(\mathrm{kg} \mathrm{ha}^{-1}\right)\end{array}$ \\
\hline 0 & $64.40 \pm 1.57 \mathrm{a}$ & $8.37 \pm 2.39 \mathrm{a}$ & $8267.08 \pm 861.43 \mathrm{a}$ \\
15 & $67.60 \pm 1.44 \mathrm{a}$ & $4.63 \pm 1.86 \mathrm{a}$ & $9543.28 \pm 1164.41 \mathrm{a}$ \\
30 & $68.40 \pm 0.87 \mathrm{a}$ & $2.79 \pm 1.58 \mathrm{a}$ & $9224.89 \pm 829.13 \mathrm{a}$ \\
Without cage & $67.20 \pm 2.27 \mathrm{a}$ & $5.96 \pm 2.13 \mathrm{a}$ & $8854.78 \pm 1367.92 \mathrm{a}$ \\
\hline
\end{tabular}

${ }^{(1)}$ Means followed by the same letter, in the column, do not differ significantly by the Tukey's test at $5 \%$ of probability.

constant supply of host and prey. Besides, the reduced size of experimental units might have facilitated their colonization by natural enemies and the efficiency of biological control.

Results show the necessity of developing new studies for biological control programs of S. frugiperda with this parasitoid in corn fields.

\section{Conclusions}

1. C. flavicincta shows parasitism up to $46.9 \%$ of S. frugiperda on corn plants with release of 30 pairs per 125 plants as economic threshold.

2. Natural parasitism (plots without cages) by C. flavicincta accounts for $4.45 \%$ within a total of larvae's mortality of $21.49 \%$.

3. Natural biological control and liberation of 30 pairs of C. flavicincta reduces significantly damage of S. frugiperda although not enough to produce significant differences on final stand and productivity.

\section{Acknowledgements}

To Geraldo Fonseca, Mauro Paulinelli and Walkíria Barbosa, for assistance in the field and laboratory; to Embrapa Milho e Sorgo, for facilities; to Conselho Nacional de Desenvolvimento Científico e Tecnológico (CNPq) and Fundação de Amparo à Pesquisa do Estado de Minas Gerais (Fapemig), for financial support.

\section{References}

BAGGEN, L.R.; GURR, G.M. The influence of food on Copidosoma koehleri (Hymenoptera: Encyrtidae), and the use of flowering plants as a habitat management tool to enhance biological control of potato 
moth, Phthorimaea operculella (Lepidoptera: Gelechiidae). Biological Control, v.11, p.9-17, 1998.

CARVALHO, R.P.L. Pragas do milho. In: PATERNIANI, E. (Ed.). Melhoramento e produção de milho no Brasil. Piracicaba: Fundação Cargill, 1978. p.505-570.

CRUZ, I. A lagarta-do-cartucho na cultura do milho. Sete Lagoas: Embrapa-CNPMS, 1995. 45p. (Circular Técnica, 21).

CRUZ, I. Métodos de criação de agentes entomófagos de Spodoptera frugiperda (J.E. Smith). In: BUENO, V.H.P. (Ed.). Controle biológico de pragas: produção massal e controle de qualidade. Lavras: Ufla, 2000. p.111-135.

CRUZ, I.; LIMA, D.A.N.; FIGUEIREDO, M.L.C.; VALICENTE, F.H. Aspectos biológicos do parasitóide Campoletis flavicincta (Ashmead) criado em lagartas de Spodoptera frugiperda (Smith). Anais da Sociedade Entomológica do Brasil, v.24, p.201-208, 1995.

CRUZ, I.; TURPIN, F.T. Efeito da Spodoptera frugiperda em diferentes estádios de crescimento da cultura de milho. Pesquisa Agropecuária Brasileira, v.17, p.355-359, 1982.

CRUZ, I.; FIGUEIREDO, M.L.C.; GONÇALVES, E.P.; LIMA, D. A.N.; DINIZ, E.E. Efeito da idade de lagartas de Spodoptera frugiperda (Smith) (Lepidoptera: Noctuidae) no desempenho do parasitóide Campoletis flavicincta (Ashmead) (Hymenoptera: Ichneumonidae) e consumo foliar por lagartas parasitadas e nãoparasitadas). Anais da Sociedade Entomológica do Brasil, v.26, p.229-234, 1997.

FUESTER, R.W.; TAYLOR, P.B.; GROCE, J.C. Reproductive response of Glyptapanteles flavicoxis (Hymenoptera: Braconidae) to various densities and instar of the gypsy moth, Lymantria dispar
(Lepidoptera: Lymantriidae). Annals of the Entomological Society of America, v.80, p.750-757, 1987.

LINGREN, P.D.; LUKEFAHR, M.J. Effects of nectariless cotton on caged populations of Campoletis sonorensis. Environmental Entomology, v.6, p.586-588, 1977.

LITTEL, R.C.; MILLIKEN, G.A.; STROUP, W.W.; WOLFINGER, R.D. SAS system for mixed models. Cary: SAS Institute, 1996. $633 \mathrm{p}$.

LUCK, R.F.; SHEPARD, B.M.; KENMORE, P.E. Evaluation of biological control with experimental methods. In: BELLOWS, T.S.; FISHER, T W. (Ed.). Handbook of Biological Control. San Diego: Academic Press, 1999. p.225-270.

MATOS NETO, F.C. Estudos sobre Campoletis flavicincta (Ashmead) (Hymenoptera: Ichneumonidae), parasitóide de larvas de Spodoptera frugiperda (Smith) (Lepidoptera: Noctuidae) na cultura do milho (Zea mays). 2003. 93p. Tese (Doutorado) - Universidade Federal de Viçosa, Viçosa.

NOBLE, L.W.; GRAHAM, H.M. Behavior of Campoletis perdistinctus (Viereck) as a parasite of the tobacco budworm. Journal of Economic Entomology, v.59, p.1118-1120, 1966.

SAS INSTITUTE (Cary, United States). SAS/STAT user's guide: version 6. $4^{\text {th }}$ ed. Cary, 1989. v.2.

VAN DRIESCHE, R.G.; BELLOWS JUNIOR, T. VAN. S. Biological control. New York: Chapman \& Hall, 1996. 539p.

ZAKI, F.N.; ELSAADANY, G.; GOMAA, A.; SALEH, M. Some biological factors affecting the production of the larval parasitoid Bracon brevicornis Wesm. (Hym., Braconidae). Journal of Applied Entomology, v.118, p.413-418, 1994. 